\title{
Puff laddy: a 5-year-old-boy with forehead swelling
}

\author{
Laura Cannon, Eric Zwemer, John R Stephens
}

Department of Pediatrics, UNC Health Care System, Chapel Hill, North Carolina, USA

\section{Correspondence to}

Dr Laura Cannon,

laura.cannon@unchealth.unc. edu

Accepted 19 November 2017

\section{DESCRIPTION}

A 5-year-old boy presented with forehead swelling in the setting of a recent sinus infection. His initial symptoms were fever and nasal congestion for which he was prescribed a 10-day course of antibiotics, completed 3 days prior to admission. He subsequently developed unsteady gait, photophobia, headache, vomiting and progressive forehead swelling. He was noted to have central forehead oedema and tenderness without overlying erythaema (figure 1). There were no neurological or ophthalmological deficits. Magnetic Resonance Imaging (MRI)/Magnetic Resonance Venography (MRV) of the head demonstrated a $3.5 \times 1.2 \times 3.9 \mathrm{~cm}$ subgaleal abscess with communication to the frontal sinuses as well as osteomyelitis of the frontal bone (figure 2). The patient underwent surgical drainage of the abscess with evacuation of purulent fluid (figure 3). Culture from the procedure grew Streptococcus anginosus. He clinically improved following surgery and was transitioned home to complete a 21-day total course of antibiotics.

The patient's history, examination and imaging were consistent with Pott's puffy tumour, which is characterised by subperiosteal abscess of the frontal bone with associated osteomyelitis. It most commonly affects adolescents and typically follows frontal sinusitis or trauma. Younger children, as in our case, are less commonly

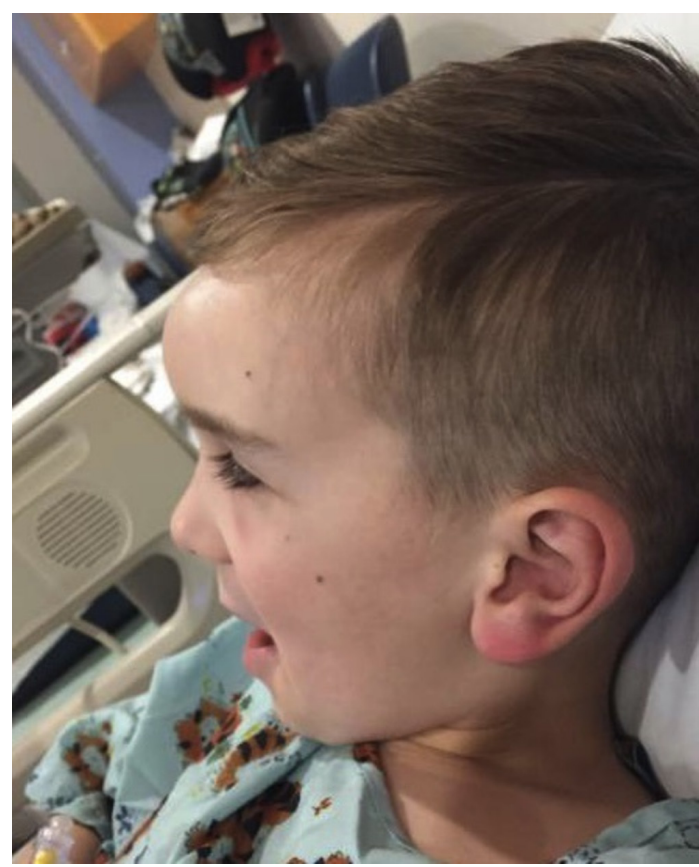

Figure 1 Profile of patient with forehead swelling at admission.

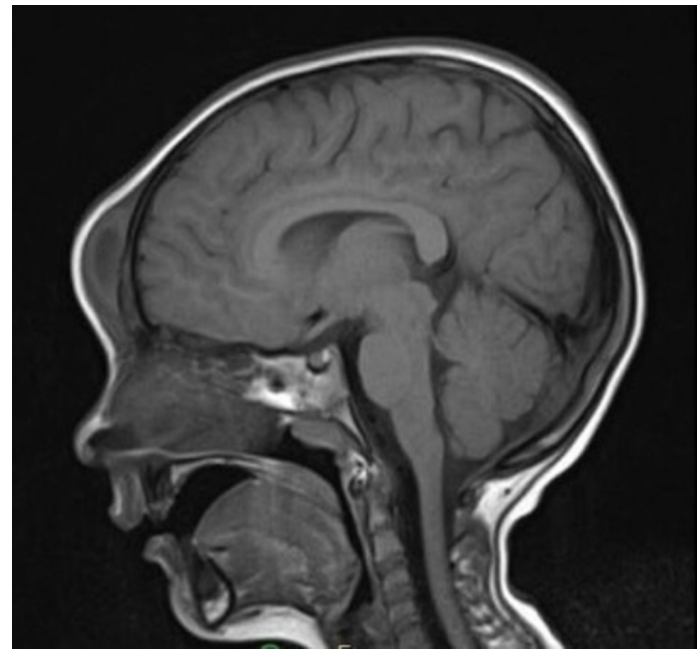

Figure 2 Sagittal T1-weighted MRI demonstrating subgaleal abscess communicating with frontal sinus and frontal bone osteomyelitis.

affected as frontal sinuses do not typically develop until later school age. ${ }^{1}$ Common bacteria associated with this entity include typical sinus pathogens, including Streptococcus species, Staphylococcus species and Haemophilus influenzae. ${ }^{12}$ Current management recommendations for acute bacterial sinusitis include treatment with amoxicillin with or without clavulanate. ${ }^{3}$ Data are limited regarding adjuvant therapies such as topical nasal decongestants, but these therapies may also be considered in the treatment of acute bacterial sinusitis. There are a number of serious complications associated with Pott's puffy tumour, including subdural empyema, brain/epidural abscess and venous sinus thrombosis. Treatment requires prompt diagnosis and

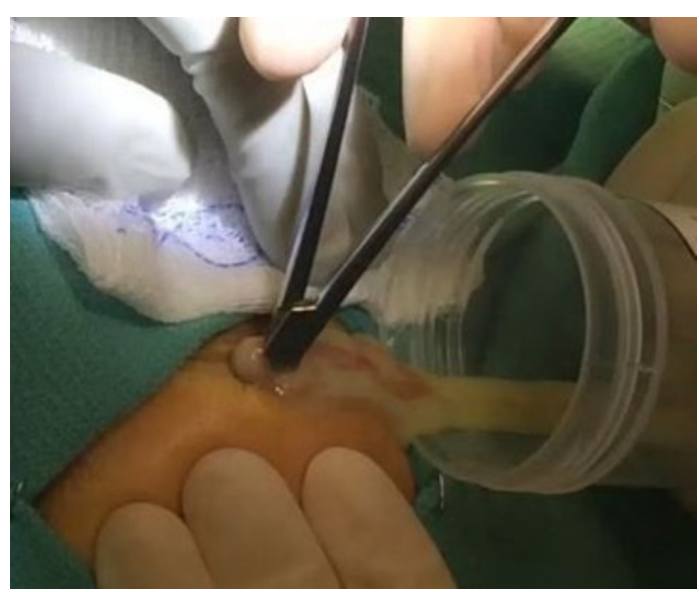

Figure 3 Purulent material expressed during surgical drainage. 


\section{Learning points}

- Forehead swelling in a child with sinus symptoms should be considered due to Pott's puffy tumour until proven otherwise.

- Pott's puffy tumour requires prompt treatment, including surgical drainage and antibiotics covering sinus pathogens, to avoid serious complications.

management, including surgical debridement and intravenous antibiotics.

Contributors All authors contributed to the manuscript as follows: LC, JS and EZ - clinical care of this patient in the hospital. LC - drafting the article. LC and JS revisions of the article. LC, JS and EZ-final approval of the version to be published. All authors read and approved the final manuscript.
Competing interests None declared.

Patient consent Guardian consent obtained.

Provenance and peer review Not commissioned; externally peer reviewed.

(c) BMJ Publishing Group Ltd (unless otherwise stated in the text of the article) 2017. All rights reserved. No commercial use is permitted unless otherwise expressly granted.

\section{REFERENCES}

1 Suwan PT, Mogal S, Chaudhary S. Pott's puffy tumor: an uncommon clinical entity. Case Rep Pediatr 2012;2012:386104.

2 Haider HR, Mayatepek E, Schaper J, et al. Pott's puffy tumor: a forgotten differential diagnosis of frontal swelling of the forehead. J Pediatr Surg 2012;47:1919-21.

3 Wald ER, Applegate KE, Bordley C, et al. Clinical practice guideline for the diagnosis and management of acute bacterial sinusitis in children aged 1 to 18 years. Pediatrics 2013:132:e262-280.

Copyright 2017 BMJ Publishing Group. All rights reserved. For permission to reuse any of this content visit http://group.bmj.com/group/rights-licensing/permissions.

BMJ Case Report Fellows may re-use this article for personal use and teaching without any further permission.

Become a Fellow of BMJ Case Reports today and you can:

- Submit as many cases as you like

- Enjoy fast sympathetic peer review and rapid publication of accepted articles

- Access all the published articles

Re-use any of the published material for personal use and teaching without further permission

For information on Institutional Fellowships contact consortiasales@bmjgroup.com

Visit casereports.bmj.com for more articles like this and to become a Fellow 